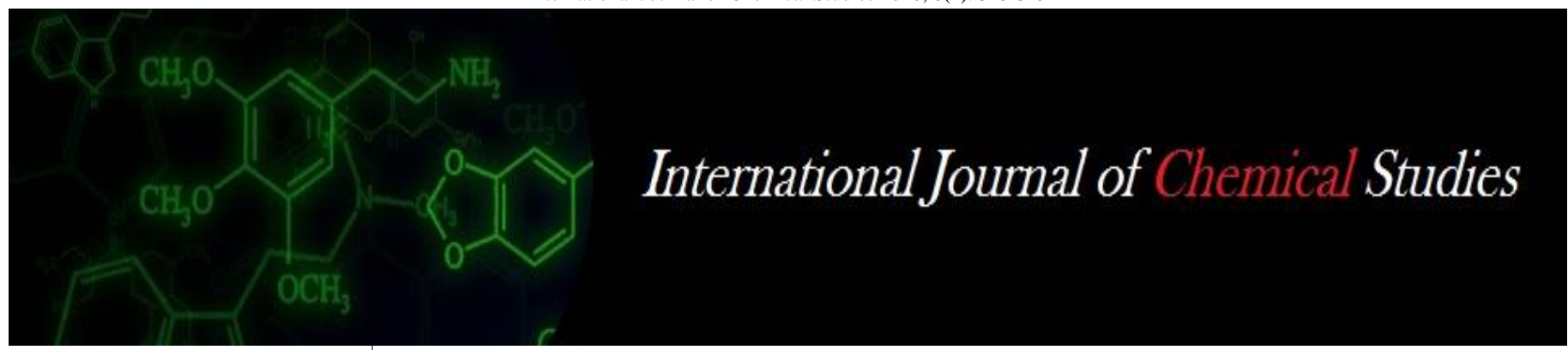

P-ISSN: 2349-8528

E-ISSN: 2321-4902

IJCS 2020; 8(1): 515-519

(C) 2020 IJCS

Received: 28-11-2019

Accepted: 30-12-2019

Nasrullah Naseh

Department of Agronomy,

CCS Haryana Agricultural

University, Hisar, Haryana, India

\section{AK Dhaka}

Department of Agronomy, CCS Haryana Agricultural University, Hisar, Haryana, India

Bhagat Singh

Department of Agronomy, CCS Haryana Agricultural University, Hisar, Haryana, India

\section{Amit Kumar}

Department of Agronomy, CCS Haryana Agricultural University, Hisar, Haryana, India

\section{Axay Bhuker}

Department of Seed Science and Technology, CCS Haryana Agricultural University, Hisar, Haryana, India
Corresponding Author: AK Dhaka

Department of Agronomy, CCS Haryana Agricultural University, Hisar, Haryana, India

\section{Suitable genotype and optimization of seed rate for late sown wheat}

\author{
Nasrullah Naseh, AK Dhaka, Bhagat Singh, Amit Kumar and Axay \\ Bhuker
}

DOI: https://doi.org/10.22271/chemi.2020.v8.i1g.8310

\begin{abstract}
A field experiment was conducted to identify suitable genotype and seed rate of wheat under late sown conditions during Rabi season of 2017-18 at Research Farm of CCS Haryana Agricultural University, Hisar. Experiment was laid out in split plot design with four replications. The experiment was comprised of three wheat genotypes viz. WH 1124, HD 3059 and DBW 90 as main plot treatments and five seed rates viz. 100.0, 112.5, 125.0, 137.5 and $150.0 \mathrm{~kg} / \mathrm{ha}$ as sub plot treatments. Among genotypes, WH 1124 was found most suitable wheat genotype for late sown condition, produced significantly tallest plant $(98.2 \mathrm{~cm})$, highest dry matter accumulation/mrl (153.4 g), higher LAI at 90 DAS (4.54), lowest leaf senescence score at $30 \mathrm{DAA}$ (9.09), higher total tillers/mrl (88.6), highest effective tillers per mrl (85.2), grains per spike (53.5), spikelets per spike (18.3), test weight (38.7) resulted in highest grain $(4,843$ $\mathrm{kg} / \mathrm{ha})$, straw $(7,015 \mathrm{~kg} / \mathrm{ha})$ and biological yield $(11,858 \mathrm{~kg} / \mathrm{ha})$. While among different seed rates, seed rate of $150 \mathrm{~kg} / \mathrm{ha}$ was found optimum to obtain higher yield of late sown wheat produced significantly tallest plant $(98.4 \mathrm{~cm})$, highest dry matter accumulation/mrl $(153.6 \mathrm{~g})$, higher LAI at 90 DAS (4.50), higher total number of tillers/mrl (91.3), highest effective tillers (86.5), grains per spike (50.5), highest grain yield (4,909 kg/ha), straw yield $(6,991 \mathrm{~kg} / \mathrm{ha})$ and biological yield $(11,900 \mathrm{~kg} / \mathrm{ha})$. However,, spike length, number of spikelets per spike was not affected significantly by various seed rates. Among genotypes, maximum days to attain 50 per cent heading ( 75.6 days) and 50 per cent anthesis (79.1 days) was taken by HD 3059 and maximum duration (109 days) to achieve maturity was observed in DBW 90. Phenological stages of wheat were not affected significantly by different seed rates. Highest gross returns (₹130,562/ha), net returns (₹52,735/ha) and B: C (1.68) were obtained with WH 1124. Among different seed rates inspite of having highest cost of cultivation (₹78,353/ha), highest gross returns (₹131,259/ha), net returns (₹52,906/ha) and B: C (1.68) was obtained in wheat sown at seed rate of $150.0 \mathrm{~kg} / \mathrm{ha}$.
\end{abstract}

Keywords: Wheat genotypes, seed rates, phenological stages, productivity, economics

\section{Introduction}

Wheat (Triticum aestivum L.) is the world's largest cultivated cereal crop, which belongs to family Poaceae and genus Triticum. India is one of the largest wheat producing country after China and contributes more than 30 per cent to the world wheat production. India produced about 97.4 million tons of wheat from an area of 30.7 million hectare with an average productivity of $3172 \mathrm{~kg} \mathrm{ha}^{-1}$ (ICAR-IIWBR, 2017) ${ }^{[6]}$. Wheat is the most important Rabi cereal crop of Northern India, which is the second most important staple crop after rice in India. Haryana, which is one of the major wheat growing state, produced 11.5 million tons of wheat from 2.6 million hectares area with an average productivity of $4514 \mathrm{~kg} \mathrm{ha}^{-1}$ during 2016-17 (Anonymous, 2017) ${ }^{[2]}$.

Wheat sowing is delayed mainly due to late harvesting of Kharif crops in northern part of country. Different genotypes have their own mechanisms to cope up with heat stress like rolling, shedding and thickening of leaves, reduction in leaf size and duration of growth, transpirational cooling and other adjustments in morphology (Wahid et al., 2007) ${ }^{[22]}$. Crop genotypes may vary in their growth behaviour and yield contributing factors viz., tillers $/ \mathrm{m}^{2}$, spike $/ \mathrm{m}^{2}$, grains/spike, grain weight. The appropriate combination of these yield attributes is needed for harvesting maximum productivity. Generally, among wheat yield attributes, the most significant contributor is spikes $/ \mathrm{m}^{2}$. Depending on the effective tillering of a cultivar, optimum spike density can be achieved through seed rate adjustments. 
The varieties having high tillering ability can contribute higher yield at low seed rate and vice-versa (Chhokar et al., 2017) ${ }^{[4]}$.

Among the agronomic factors, seed rate is an important production factor which determines the crop vigour and ultimate yield of the crop (Korres and Williams 2002) ${ }^{[9]}$, So, optimum planting geometry is a pre-requisite to realize the full genetic potential of a variety, which can be achieved through seed rate. With increasing seed rate there is an increase in yield mainly through more spikes per unit area, which compensated for a decrease in seeds per spike (Chhokar et al. 2017) ${ }^{[4]}$. Through increase in seed rate, the canopy expands more rapidly, more radiation is intercepted and more dry matter is produced which results in efficient utilization of environmental resources by changing relative importance of intra and interplant competition for light, water and nutrients during crop development and thereby affects wheat yield considerably (Naveed et al., 2014) ${ }^{[14]}$. Low seed rate increase the inter-plants competition during the grain filling stage because of the tendency to produce more spike bearing tillers (Marshall and Ohms, 1987) ${ }^{[13]}$. Hence, it was a general assumption that low seed rates increase the weight of the single spikes, but decrease the number of spikes per unit area and the situation is vice versa in the higher seed rates, i.e. higher number of spikes per unit area but lesser grain weight per spike (Tompkins et al., 1991) ${ }^{[21]}$. One of the drawbacks of using higher seed rate above optimum value is that higher seed densities increase the occurrence of lodging and diseases leading to grain yield reduction (Beuerlein and Lafever, 1989) [3]. Therefore, keeping the above facts in consideration, the current experiment was conducted to find out the suitable genotype and optimum seed rate of wheat under late sown conditions.

\section{Materials and Methods}

The field experiment was conducted during Rabi season of 2017-18 at Research Farm of CCS Haryana Agricultural University, Hisar. The experiment was laid out in split plot design with four replications. The experiment was comprised of three wheat genotypes viz. WH 1124, HD 3059 and DBW 90 as main plot treatments and five seed rates viz. 100.0, $112.5,125.0,137.5$ and $150.0 \mathrm{~kg} / \mathrm{ha}$ as sub plot treatments. All agronomic practices were applied evenly to all plots as per the recommendation of CCS Haryana Agricultural University, Hisar.

After harvesting and bundling, the wheat bundles were sundried for 4 to 5 days. After recording of biological yield, bundles were threshed separately and weight of collected grains was converted into $\mathrm{kg} / \mathrm{ha}$.

Cost of cultivation and gross returns (₹/ha) of various treatments were calculated on the basis of approved inputs and output cost fixed by Directorate of Farm, CCS HAU, Hisar. Net returns (₹/ha) were worked out by subtracting the total cost of cultivation of each treatment from the gross income of respective treatment. Whereas, Benefit cost ratio (B: C) was worked out by following formula:

$\mathrm{B}: \mathrm{C}=\frac{\text { Gross returns }(₹ / \mathrm{ha})}{\text { Cost of cultivation }(₹ / \mathrm{ha})}$

The experimental data was statistically analyzed by the methods of analysis of variance (ANOVA) as described by Panse and Sukhatme (1985) ${ }^{[18]}$.

\section{Results and Discussion \\ Growth Parameters \\ Plant height}

The perusal of data presented in Table 1 showed that plant height of wheat was affected significantly by different genotypes and seed rates. Among different genotypes of wheat, significantly tallest plants $(98.2 \mathrm{~cm})$ were recorded in genotype WH 1124 at harvest which might be due to its genetic makeup. The finding is in line with Rawat et al. (2000) ${ }^{[19]}$, who reported significant difference in plant height of various wheat genotypes due their genetic variation. Whereas, among different seed rates, $150 \mathrm{~kg} / \mathrm{ha}$ produced tallest plants $(98.4 \mathrm{~cm})$ which was statistically at par with seed rates of $137.5 \mathrm{~kg} / \mathrm{ha}(97.9 \mathrm{~cm})$ and $125.0 \mathrm{~kg} / \mathrm{ha}(97.4$ $\mathrm{cm})$, but significantly higher over rest of the seed rates. The taller plants with higher seed rates might be due to dense population which increased competition for solar radiation among plants and ultimately lead to increase plant height. The result is in line with Khalil et al. $(2011)^{[8]}$.

\section{Dry matter accumulation}

Data in Table 1 revealed that among different genotypes, maximum dry matter $(153.4 \mathrm{~g} / \mathrm{mrl})$ per meter row length was recorded in WH 1124 at harvest which might be due to more plant height, more tillers and higher leaf area of this genotype. The result is also supported with the findings of Kumar et al. (2002) ${ }^{[10]}$. Whereas, among different seed rates, maximum dry matter accumulation per meter row length $(153.6 \mathrm{~g} / \mathrm{mrl})$ was observed with highest seed rate of $150.0 \mathrm{~kg} / \mathrm{ha}$ which was statistically at par with seed rate of $137.5 \mathrm{~kg} / \mathrm{ha}$, but significantly higher over rest of the seed rates. It might be due to dense plant population, taller plants and higher leaf area index, which ultimately increased accumulation of photosynthates and resulted in higher dry matter accumulation. Similar result was also reported by Noy-Meir and Briske (2002) ${ }^{[16]}$.

\section{Leaf area index}

The data showed in Table 1 leaf area index (LAI) of wheat was not affected significantly by different genotypes Whereas, among various seed rates, highest seed rate of 150 $\mathrm{kg} / \mathrm{ha}$ at 90 DAS produce maximum LAI (4.50) which was statistically at par with seed rate of $137.5 \mathrm{~kg} / \mathrm{ha}$ (4.36) and $125.0 \mathrm{~kg} / \mathrm{ha}(4.23)$. It might be due to higher number of tillers which resulted in higher number of leaves which ultimately increased positively LAI of the crop compared to rest of the genotypes. The findings are in line with those of Pandey et al. $(1998)^{[17]}$.

\section{Phenological studies}

The perusal data (Table 1) indicated that days to emergence were not significantly affected among different genotypes. Minimum days to 50 per cent heading (72.6 days) were taken by DBW 90, which was closely followed by WH 1124 and HD 3059. Likewise minimum days to 50 per cent anthesis (78.0 days) were recorded by DBW 90, which was statistically at par with WH 1124. Whereas, significantly higher days to achieve maturity (111.1 days) were recorded by DBW 90, which, was statistically at par with WH 1124.

The same variation among wheat genotypes to attain different phonological stages were reported by Gupta et al. (2002) ${ }^{[5]}$ and Sarker et al. (2009) ${ }^{[20]}$. As attainment of phenological stages are related to genetic makeup of the genotypes. Different phenological stages were affected non significantly 
by various seed rates. These results are agreed with finding of Nizamani et al. (2014) ${ }^{[15]}$.

\section{Yield attributes}

At harvest, genotype WH 1124 resulted in significantly higher number of total tillers (88.6) as compared to other genotypes which might be due to higher tillering habit of the genotype (Table 2). The result is in line with those of Jat and Singh (2004) ${ }^{[7]}$. Among seed rates, seed rate of $150 \mathrm{~kg} / \mathrm{ha}$ being at par with seed rate of $137.5 \mathrm{~kg} / \mathrm{ha}$ resulted in significantly higher number of total tillers (91.3) as compared to rest of the seed rates. It might be due to higher plant population, tillering and better leaf area development, which resulted in maximum solar radiation interception and adequate synthesis and translocation of carbohydrates to all growing auxiliary buds which ultimately resulted in higher number of total tillers. The results are in conformity with findings of Kumar et al. (2018) [11].

Data revealed that numbers of effective tillers per meter row length were significantly higher (85.2 and 86.5) in WH 1124 and at highest seed rate of $150 \mathrm{~kg} / \mathrm{ha}$, respectively. Length of spike was not affected significantly by different genotypes as well as various seed rates. Longest spike $(9.8 \mathrm{~cm})$ was observed in HD 3059 among genotypes; and at seed rates of $100 \mathrm{~kg} / \mathrm{ha}$ among various seed rates. Significantly higher number of grains per spike was reported in WH 1124 (53.5) among different genotypes and at lowest seed rate of 100 $\mathrm{kg} / \mathrm{ha}$ (52.6) which was statistically at par with seed rate of $112.5 \mathrm{~kg} / \mathrm{ha}(51.8)$. Significantly higher number of spikelets per spike (18.3) were observed in WH 1124 over DBW 90 whereas, number of spikelets per spike was not affected significantly by various seed rates. The results are in line with those of Kumar et al. (2018) ${ }^{[11]}$ who observed non-significant effect of different seed rates on number of spikelets per spike.
Significantly boldest grains $(38.7 \mathrm{~g})$ were obtained in $\mathrm{WH}$ 1124 among genotypes and at lowest seed rate of $100 \mathrm{~kg} / \mathrm{ha}$, which was statistically at par with seed rates of 112.5 and $125.0 \mathrm{~kg} / \mathrm{ha}$. The results might be attributed to genetic makeup of the genotypes also reported by Akhter et al. (2017) [1].

\section{Yield and Economics}

The data of yield presented in Table 3 revealed that grain and biological yield were significantly affected by genotypes and seed rates. Among different genotypes, biological yield $(11,858 \mathrm{~kg} / \mathrm{ha})$, grain yield $(4,843 \mathrm{~kg} / \mathrm{ha})$ and straw yield $(7,015 \mathrm{~kg} / \mathrm{ha})$ was significantly higher in WH 1124 over rest of genotypes except straw yield which was statistically at par with HD 3059. The results might be attributed to higher yield attributes of genotypes. While comparing the different seed rates, significantly higher biological yield $(11,900 \mathrm{~kg} / \mathrm{ha})$, grain yield $(4,909 \mathrm{~kg} / \mathrm{ha})$, straw yield $(6,991 \mathrm{~kg} / \mathrm{ha})$ and harvest index $(41.4 \%)$ was obtained with highest seed rate of $150 \mathrm{~kg} / \mathrm{ha}$, which was statistically at par with seed rates of 137.5 and $125.0 \mathrm{~kg} / \mathrm{ha}$ in terms of biological and grain yield. It might be due to higher number of effective tillers per unit area. The results were in collaboration of Malik et al. (2009) [12].

Data of economics mentioned in Table 3 revealed that among genotypes, maximum gross returns (₹130,562/ha), net returns (₹52,735/ha) and B: C (1.68) was obtained with WH 1124. Among seed rates, highest seed rate of $150.0 \mathrm{~kg} / \mathrm{ha}$ gave maximum gross returns (₹131,259/ha), net returns (₹52,906/ha) and B: C (1.68), which was closely followed by seed rates of 137.5 and $125.0 \mathrm{~kg} / \mathrm{ha}$ which might be due to higher yield of the crop. The finding is in line with those of Kumar et al. (2002) ${ }^{[10]}$.

Table 1: Effect of sowing dates and wheat genotypes on growth and phenological stages of wheat

\begin{tabular}{|c|c|c|c|c|c|c|c|}
\hline Treatments & $\begin{array}{c}\text { Plant height } \\
\text { at harvest }(\mathrm{cm})\end{array}$ & \begin{tabular}{|c} 
Dry matter accumulation \\
at harvest $(\mathrm{g} / \mathrm{mrl})$
\end{tabular} & $\begin{array}{c}\text { Leaf Area Index at } \\
90 \text { DAS }\end{array}$ & \begin{tabular}{|c|} 
Days to \\
$50 \%$ emergence
\end{tabular} & \begin{tabular}{|c|} 
Days to \\
$50 \%$ heading \\
\end{tabular} & $\begin{array}{c}\text { Days to } \\
50 \% \text { anthesis }\end{array}$ & $\begin{array}{c}\text { Days to } \\
\text { maturity }\end{array}$ \\
\hline \multicolumn{8}{|c|}{ Genotypes } \\
\hline WH 1124 & 98.2 & 153.4 & 4.54 & 11.8 & 73.8 & 78.1 & 110.2 \\
\hline HD 3059 & 95.5 & 146.2 & 4.14 & 11.3 & 75.6 & 79.1 & 109.2 \\
\hline DBW 90 & 97.0 & 143.6 & 3.84 & 11.2 & 72.6 & 78.0 & 111.1 \\
\hline $\mathrm{SEm} \pm$ & 0.3 & 0.6 & 0.01 & 0.3 & 0.1 & 0.2 & 0.3 \\
\hline C.D. at $5 \%$ & 1.1 & 2.1 & NS & NS & 0.3 & 0.7 & 1 \\
\hline \multicolumn{8}{|c|}{ Seed rate (kg/ha) } \\
\hline 100 & 95.0 & 141.1 & 3.66 & 11.3 & 74.2 & 78.4 & 110.2 \\
\hline 112.5 & 95.7 & 143.9 & 4.11 & 11.5 & 73.7 & 78.8 & 110.2 \\
\hline 125 & 97.4 & 148.0 & 4.23 & 11.5 & 73.9 & 78.1 & 110.1 \\
\hline 137.5 & 97.9 & 152.0 & 4.36 & 11.3 & 73.8 & 78.2 & 110.1 \\
\hline 150 & 98.4 & 153.6 & 4.50 & 11.3 & 74.3 & 78.5 & 110.3 \\
\hline $\mathrm{SEm} \pm$ & 0.8 & 1.1 & 0.09 & 0.1 & 0.4 & 0.4 & 0.1 \\
\hline C.D. at $5 \%$ & 2.2 & 3.3 & 0.27 & NS & NS & NS & NS \\
\hline
\end{tabular}

Table 2: Effect of sowing dates and wheat genotypes on yield attributing characters of wheat

\begin{tabular}{|c|c|c|c|c|c|c|}
\hline Treatments & $\begin{array}{c}\text { Total tillers/mrl } \\
\text { (No.) }\end{array}$ & \begin{tabular}{|c|}
$\begin{array}{c}\text { Effective tillers/mrl } \\
\text { (No.) }\end{array}$ \\
\end{tabular} & $\begin{array}{c}\begin{array}{c}\text { Spike length } \\
(\mathrm{cm})\end{array} \\
\end{array}$ & $\begin{array}{l}\text { Grains per } \\
\text { spike (No.) }\end{array}$ & \begin{tabular}{|c}
$\begin{array}{c}\text { Spikelets per spike } \\
\text { (No.) }\end{array}$ \\
\end{tabular} & $\begin{array}{l}\text { 1000-grain weight } \\
\text { (g) }\end{array}$ \\
\hline \multicolumn{7}{|c|}{ Genotypes } \\
\hline WH 1124 & 88.6 & 85.2 & 9.6 & 53.5 & 18.3 & 38.7 \\
\hline HD 3059 & 86.7 & 82.9 & 9.8 & 51.1 & 17.8 & 37.6 \\
\hline DBW 90 & 85.1 & 81.7 & 9.7 & 49.7 & 17.3 & 37.4 \\
\hline $\mathrm{SEm} \pm$ & 0.5 & 0.6 & 0.1 & 0.4 & 0.2 & 0.2 \\
\hline C.D. at $5 \%$ & 1.6 & 2.2 & NS & 1.6 & 0.7 & 0.8 \\
\hline \multicolumn{7}{|c|}{ Seed rate $(\mathrm{kg} / \mathrm{ha})$} \\
\hline 100 & 82.1 & 79.3 & 9.8 & 52.6 & 18.2 & 38.7 \\
\hline 112.5 & 84.0 & 81.4 & 9.7 & 51.8 & 17.9 & 38.3 \\
\hline 125 & 87.3 & 83.8 & 9.6 & 51.2 & 17.7 & 37.8 \\
\hline
\end{tabular}




\begin{tabular}{|c|c|c|c|c|c|c|}
\hline 137.5 & 89.3 & 85.1 & 9.5 & 51.0 & 17.6 & 37.5 \\
\hline 150 & 91.3 & 86.5 & 9.5 & 50.5 & 17.4 & 37.4 \\
\hline SEm \pm & 0.8 & 0.9 & 0.2 & 0.4 & 0.2 & 0.3 \\
\hline C.D. at 5\% & 2.4 & 2.5 & NS & 1.1 & NS & 1 \\
\hline
\end{tabular}

Table 3: Effect of sowing dates and wheat genotypes yield and economics of wheat

\begin{tabular}{|c|c|c|c|c|c|c|c|}
\hline Treatments & $\begin{array}{c}\begin{array}{c}\text { Grain yield } \\
\text { (kg/ha) }\end{array} \\
\end{array}$ & $\begin{array}{c}\text { Straw yield } \\
\text { (kg/ha) }\end{array}$ & $\begin{array}{c}\text { Biological yield } \\
\text { (kg/ha) }\end{array}$ & \begin{tabular}{|c}
$\begin{array}{c}\text { Harvest Index } \\
(\%)\end{array}$ \\
\end{tabular} & $\begin{array}{c}\begin{array}{c}\text { Gross returns } \\
\text { (Rs./ha) }\end{array} \\
\end{array}$ & $\begin{array}{l}\text { Net returns } \\
\text { (Rs./ha) }\end{array}$ & B: $\mathbf{C}$ \\
\hline \multicolumn{8}{|c|}{ Genotypes } \\
\hline WH 1124 & 4,843 & 7,015 & 11,858 & 40.9 & 130,562 & 52,735 & 1.68 \\
\hline HD 3059 & 4,695 & 6,871 & 11,566 & 40.6 & 126,839 & 49,012 & 1.63 \\
\hline DBW 90 & 4,634 & 6,718 & 11,351 & 40.8 & 124,908 & 47,080 & 1.61 \\
\hline $\mathrm{SEm} \pm$ & 46 & 57 & 92 & 0.2 & & & \\
\hline C.D. at $5 \%$ & 164 & 201 & 326 & NS & & & \\
\hline \multicolumn{8}{|c|}{ Seed rate $(\mathrm{kg} / \mathrm{ha})$} \\
\hline 100 & 4,475 & 6,731 & 11,207 & 39.9 & 121,806 & 44,503 & 1.58 \\
\hline 112.5 & 4,583 & 6,739 & 11,322 & 40.5 & 124,094 & 46,530 & 1.60 \\
\hline 125 & 4,790 & 6,887 & 11,677 & 41 & 129,033 & 51,206 & 1.66 \\
\hline 137.5 & 4,863 & 6,991 & 11,853 & 41 & 130,989 & 52,900 & 1.68 \\
\hline 150 & 4,909 & 6,991 & 11,900 & 41.4 & 131,259 & 52,906 & 1.68 \\
\hline $\mathrm{SEm} \pm$ & 65 & 80 & 130 & 0.3 & & & \\
\hline C.D. at $5 \%$ & 186 & NS & 375 & 0.8 & & & \\
\hline
\end{tabular}

\section{Conclusion}

Among genotypes, WH 1124 was found most suitable and economical wheat genotype for late sown conditions, and among seed rates, seed rate of $150 \mathrm{~kg} / \mathrm{ha}$ was found optimum to obtain higher yield and economical performance for late sown wheat.

\section{Reference}

1. Akhter MM, Sabagh AE, Alam MN, Hasan MK, Hafez $\mathrm{E}$, Barutcular C et al. Determination of seed rate of wheat (Triticum aestivum L.) varieties with varying seed size. Scientific Journal of Crop Science. 2017; 6(3):161-167.

2. Anonymous. Progress report of all India Coordinated Wheat and Barely Improvement Project 2016-17, Director's report. Ed. G.P. Singh, ICAR-Indian Institute of Wheat and Barely Research, Karnal, India, 2017.

3. Beuerlein JE, Lafever HN. Row spacing and seeding rate effects on soft red winter wheat yield, its components and agronomic characteristics. Applied of Agricultural Research. 1989; 4:106-110.

4. Chhokar RS, Sharma RK, Gill SC, Kumar R. Influence of tillage, cultivar, seed rate and planting geometry on wheat yield. Journal of Wheat Research. 2017; 9(1):1220.

5. Gupta NK, Shukla DS, Pande PC. Interaction of yield determining parameters in late sown wheat genotypes. Indian Journal of Plant Physiol. 2002; 7(3):264-269.

6. ICAR-IIWBR. Director's Report of AICRP on wheat and Barley 2016/17 Ed. G.P. Singh. ICAR-Indian Institute of Wheat and Barley Research, Karnal, Haryana, India, 2017, pp. 87.

7. Jat LN, Singh SM. Growth, yield attributes and yield of wheat (Triticum aestivum L.) under different planting patterns or cropping systems. Indian Journal of Agronomy. 2004; 49(2):111-113.

8. Khalil SK, Khan F, Rehman A, Muhammad FIDA, Amanullah KA, Shah MK et al. Dual purpose wheat for forage and grain yield in response to cutting, seed rate and nitrogen. Pakistan Journal of Botany. 2011; 43(2):937-947.

9. Korres NE, Williams Froud RJ. Effects of winter wheat cultivars and seed rate on the biological characteristics of naturally occurring Weed flora. Weed Research. 2002; 42(6):417.

10. Kumar R, Agarwal SK, Nanwal RK. Economics of bread wheat as affected by planting system, seed rate and nitrogen fertilization in sandy loam soils of Haryana. Haryana Agricultural University Journal of Research. 2002; 32(1):23-25.

11. Kumar R, Nand V, Doharey RK, Verma SK, Raju. Effect of seed rate and weed management practices on growth parameters and dry matter accumulation of late sown wheat (Triticum aestivum L.). International Journal of Chemical Studies. 2018; 6(2):2498-2502.

12. Malik AU, Ahmad Alias M, Bukhsh HA, Hussain I. Effect of seed rates on different dates on wheat under agro-ecological conditions of Dera Ghazi Khan. Journal of Animal Plant Sciences. 2009; 19(3):126-129.

13. Marshal GC, Ohms HW. Yield response of 16 winter wheat cultivars to row spacing and seeding rate. Journal of Agronomy. 1987; 79(4-8):1027-1030.

14. Naveed K, Khan MA, Baloch MS, Ali K. Effect of different seeding rates on yield attributes of dualpurpose wheat. Sarhad Journal of Agriculture. 2014; 30(1):83-91.

15. Nizamani GH, Tunio S, Buriro UA, Keerio MI. Influence of different seed rates on yield contributing traits in wheat varieties. Journal of Plant Sciences. 2014; 2(5):232-236.

16. Noy-Meir I, Briske DD. Response of wild wheat populations to grazing in Mediterranean grasslands: the relative influence of defoliation, competition, mulch and genotype. Journal of Applied Ecology. 2002; 39(2):259278.

17. Pandey IB, Thakar SS, Singh SK. Response of timely sown wheat (Triticum aestivum L.) varieties to seed rate and fertility levels. Indian Journal of Agronomy. 1998; 44(4):745-749.

18. Panse VS, Sukhatme PV. Statistical methods for Agricultural workers (4th Edn.) ICAR Publication, New Delhi, 1985.

19. Rawat AK, Sharma RS, Dubey AK, Naik KR. Refinement of agro-techniques for improving productivity of wheat (Triticum aestivum L.) under rice (Oryza sativa)- wheat agro-system. Indian Journal of Agronomy. 2000; 45(4):636-640. 
20. Sarker MAZ, Malaker PK, Bodruzzaman M, Barma NCD. Effect of management and seed rate on the performance of wheat varieties with varying seed sizes. Bangladesh Journal of Agricultural Research. 2009; 34(3):481-492.

21. Tompkins DK, Fowler DB, Wright AT. Water use by notill winter wheat. Influence of seed rate and row spacing. Agronomy Journal. 1991; 83:766-769.

22. Wahid A, Gelani S, Ashraf M, Foolad MR. Heat tolerance in plants: an overview. Environmental and Experimental Journal of Botany. 2007; 61(3):199-223. 